\title{
Sciendo
}

\section{R\&D Investments in the European ICT sector: Implications for Business Performance}

\author{
Jan Hunady, Peter Pisar, Ina Durcekova
}

Faculty of Economics, Matej Bel University in Banska Bystrica, Slovakia

\section{Abstract}

Background: A significant share of business innovation arises from information and communication (ICT) sector. Business investment into research and development (R\&D) activities can be seen as an important basis for innovation, which can further lead to better economic performance. This can be especially true for the ICT sector. Objectives: The paper examines the share of the ICT sector on innovation and the total R\&D expenditure in selected European countries. Furthermore, our aim is to test the potential positive correlation between R\&D expenditure, productivity and the value added in the sector. Methods/Approach: The goals of the paper has been tested by empirical data analysis using the pane regression analysis. We examined panel data for 24 European countries in the 2008-2016 period. Results: The highest share of business R\&D expenditure in ICT has been captured in Nordic countries. Firms in ICT appear to be innovative above the average and represent a significant share in the total business R\&D expenditure. Conclusions: We found a positive correlation between R\&D expenditure and both value-added and apparent labour productivity in the ICT sector. We believe that this could be to some extent attributed to the innovation of products and processes. Hence, the government support in the form of R\&D tax incentives can be also beneficial for the economic performance of ICT firms. Keywords: R\&D investments, R\&D expenditure, innovation, ICT sector, business performance.

JEL main category: 031

JEL classification: M21, 032

Paper type: Research article

Received: Dec 12, 2019

Accepted: Apr 04, 2020

Citation: Hunady, J., Pisar, P., Durcekova, I. (2020), "R\&D Investments in the European ICT Sector: Implications for Business Performance", Business Systems Research, Vol. 11 , No. 3, pp. 30-44.

DOI: https://doi.org/10.2478/bsrj-2020-0025

Acknowledgements: This research was supported by Slovak Scientific Grant Agency (VEGA) under the contract 1/0385/19 "Determinants of business innovation performance on the basis of Quadruple helix model". 


\section{Introduction}

Research and development (R\&D) are considered as the main requirements for the development of innovation. Enterprises with innovation ambition need to acquire knowledge and apply results from R\&D activities. R\&D can be performed either in house by their research capacities or acquire from other subjects in innovation systems such as universities or public and private research institutions. In both cases, usually business has to invest certain financial resources to get some R\&D outputs. Hence, R\&D expenditure is mostly one of the main determinants of innovation performance in the business sector. This is also true in the ICT sector, which is often traditionally considered as one of the most innovative sectors in the economy. Innovation activities play an important role in this type of business. Innovation policies of many European countries, as well as the policies of the European Union, are often focused on support of high-tech and medium-tech industries. Concerning this, ICT together with several other sectors often gains significant attention to public policies.

Our paper deals with the problem of R\&D expenditure, with a special focus on the ICT sector in European countries. We examine the share of the ICT sector on R\&D expenditure as well as its important for innovation activities in the economy. Hence, the main goal of our paper is to examine the R\&D expenditures in European countries and identify the potential relationship between R\&D investments and selected business performance indicator. In the next chapter, we describe the background for our research as well as results of previous research focused into some extent on similar problems. Next, we also describe used methodology and data followed by interpretation and discussion of certain results and potential limitation. The final section concludes and summarizes the most important findings.

\section{Literature review}

It was proven that R\&D investment has a positive impact of economic growth (Akcali \& Sismanoglu, 2015; Falk, 2007; Gumus \& Celikay, 2015; Huňady \& Orviská, 2014) and productivity (Blanco et al., 2015; Nekrep et al., 2018) on a national level. Moreover, studies examining the impact of R\&D expenditure spent by a firm were proven to have a positive effect on productivity on firm-level (Pieri et al., 2018). It has also been shown that R\&D investment has positive effect on financial performance of a firm, such as on its profitability measured by either ROA or ROE (Apergis \& Sorros, 2014; Ayaydin \& Karaaslan, 2014; Freihat \& Kanakriyah, 2017; Shen et al., 2017; VanderPal, 2015), turnover (Park et al., 2018) or value-added (Tsang et al., 2008). It is therefore apparent that R\&D expenditures are a crucial investment for a firm.

However, it is not only important to monitor R\&D activities in an economy as a whole, but it is also interesting to examine R\&D investment across different sectors. R\&D and innovation investment tends to focus on the so-called knowledge-intensive industries in which firms mainly use R\&D to gain a competitive edge (Abdal et al., 2016). These sectors are commonly known as high-tech industries and are said to produce up to around $80 \%$ of total R\&D expenditure in some EU regions (Czarnizki \& Thorwarth, 2012). R\&D investment contributes to the increase of high-tech products export (Sandu \& Ciocanel, 2014) and the growth of high-tech industries (Karahan, 2015; Wang et al., 2013). These industries include e.g. aerospace, computers, pharmaceutical or electronics and telecommunications industries (Sandu \& Ciocanel, 2014). One of the fastest-growing high-tech sectors in many countries in the past few decades has been the ICT sector (Hanna, 2009). It is therefore not surprising that ICT has been proven to have a positive effect on economic growth (Khanna \& Sharma, 2018; Sepehrdoust, 2018; Tolica et al., 2015). Even though many papers focus on the 
role of R\&D and ICT separately, some authors argue that it is important to study the relationship and correlations between these two areas since they were shown to have complementary effects (Pieri et al., 2018; Khanna \& Sharma, 2018; Mohnen et al., 2018). Many authors studying the factors affecting the growth of ICT sector agree that one of the key driving forces of ICT industry is R\&D and innovation (Canarella \& Miller, 2018; Lindmark et al., 2010; Manjón et al., 2016; Monge-Gonzálet \& Hewitt, 2010; Stejskal et al., 2018; Tolica et al., 2015). Thus, it is understandable that reports examining the role of R\&D in the ICT sector prove that the ICT sector is the largest R\&D investor in the EU, USA and Japan (Turlea et al., 2009). This is also shown in the fact that many studies focus on the R\&D activities undertaken by firms operating in the ICT industry (Wei et al., 2011).

Table 1

Review of the studies focused on the impact of R\&D investment on innovation, growth and profitability of ICT firms

\begin{tabular}{|c|c|c|c|}
\hline \multirow[t]{2}{*}{ Author } & \multicolumn{2}{|c|}{ Sample specification } & \multirow[t]{2}{*}{ Study specifics } \\
\hline & Country & Period, data source & \\
\hline \multicolumn{4}{|c|}{ INNOVATIVE EFFORTS } \\
\hline $\begin{array}{l}\text { Agramunt and Berbel- } \\
\text { Pineda, } 2018\end{array}$ & Argentina & $\begin{array}{l}2011 \\
\text { Questionnaire survey }\end{array}$ & $\begin{array}{l}\text { R\&D investment (expressed as } \\
\text { innovative effort) is a determinant } \\
\text { of innovation }\end{array}$ \\
\hline Stejskal et al., 2018 & Germany & $\begin{array}{l}2010-2012 \\
\text { Innobarometer }\end{array}$ & $\begin{array}{l}\text { Influence of internal and external } \\
\text { R\&D expenditure contributes to } \\
\text { the creation of innovation }\end{array}$ \\
\hline \multicolumn{4}{|c|}{ GROWTH } \\
\hline Park et al., 2016 & Korea & $\begin{array}{lr}2012 & \\
\text { Daejeon } & \text { Regional } \\
\text { Economic } & \text { Receiving } \\
\text { Survey } & \\
\end{array}$ & $\begin{array}{l}\text { Innovation effort (including R\&D } \\
\text { investment) is the factor of firm's } \\
\text { successful growth }\end{array}$ \\
\hline Schröder, 2012 & Germany & $\begin{array}{l}2009-2010 \\
\text { Questionnaire survey }\end{array}$ & R\&D stimulates growth \\
\hline $\begin{array}{l}\text { Conarella and Miller, } \\
2018\end{array}$ & U.S. & $\begin{array}{l}1990-2013 \\
\text { Compustat database }\end{array}$ & R\&D facilitates growth \\
\hline Hong, 2016 & Korea & $\begin{array}{lr}\text { 1988-2013 } & \\
\text { Korean } & \text { Statistical } \\
\text { Information } & \text { Service, } \\
\text { National Science \& } \\
\text { Technology Information } \\
\text { Service }\end{array}$ & $\begin{array}{l}\text { R\&D investment is a driver of } \\
\text { growth }\end{array}$ \\
\hline \multicolumn{4}{|c|}{ PROFITABILITY } \\
\hline $\begin{array}{l}\text { Warusawitharana, } \\
2015\end{array}$ & U.S. & $\begin{array}{l}1985-2006 \\
\text { Compustat database }\end{array}$ & $\begin{array}{l}\text { The model focused on R\&D } \\
\text { intensive industries, results show } \\
\text { that R\&D investment leads to } \\
\text { higher profitability, especially in } \\
\text { the software industry }\end{array}$ \\
\hline $\begin{array}{l}\text { Koutroumpis et al., } \\
2020\end{array}$ & $\begin{array}{l}\text { Germany, } \\
\text { France, } \\
\text { Sweden, UK }\end{array}$ & $\begin{array}{l}2004-2013 \\
\text { Orbis/Amadeus dataset }\end{array}$ & $\begin{array}{l}\text { R\&D capital in ICT firms has a } \\
\text { larger effect on revenue in } \\
\text { comparison with non-ICT firms }\end{array}$ \\
\hline Lee et al., 2018 & Malaysia & $\begin{array}{l}2009-2015 \\
\text { Bloomberg database }\end{array}$ & $\begin{array}{l}\text { Intangible assets (variable } \\
\text { related to R\&D investment) is } \\
\text { shown to have a positive effect } \\
\text { on firm profitability }\end{array}$ \\
\hline Babkin et al., 2015 & $\begin{array}{l}\text { Global, } 100 \\
\text { largest firms }\end{array}$ & $\begin{array}{l}2010-2012 \\
\text { Primary sources - reports } \\
\text { of firms in the IT sector }\end{array}$ & $\begin{array}{l}\text { Increasing R\&D costs leads to } \\
\text { greater firm revenue }\end{array}$ \\
\hline
\end{tabular}

Source: Authors' work 
Authors often focus on the impact of R\&D and ICT investments on growth and profitability separately, comparing the effect of these two variables. Edquist and Henrekson (2017) proved that ICT and R\&D capital has a positive impact on valueadded growth. Mithas et al. (2012) focused on the impact of R\&D and ICT investment on the profitability on a sample of global firms and founds that while both of these expenditures have a positive effect on revenue of a firm, impact of ICT investment is greater than that of R\&D expenditure. Estrada and Dong (2020) studied coopetition on a sample of Spanish manufacturing firms and found that R\&D investment positively affects ICT investment and ICT investment in turn positively affects profitability. Hall et al. (2013) concluded that while both R\&D and ICT investment are strongly associated with innovation and productivity, R\&D is more important for innovation, while ICT is more important for productivity. The positive impact of both R\&D and ICT investment on innovation and productivity was confirmed by many other studies (Álvarez, 2016; Khanna \& Sharma, 2018; Martin \& Nguyen-Thi, 2015; Pieri et al., 2018).

However, there can also be found studies focused on the impact of R\&D investment on various growth variables in the ICT sector specifically. The main findings of these studies are summarized in Table 1.

In general, we can conclude that most of the studies found some positive consequences of R\&D activities on firms' growth, profitability and other financial and economic performance indicators.

\section{Methodology}

Concerning innovation, the ICT sector still has a special place within all different sectors. Hence, we focused our attention on research and development expenditure in this sector. Our main goal is to examine the R\&D expenditures in European countries and identify the potential relationship between R\&D investments and selected business performance indicators. In line with the aim we developed three research hypotheses as follows:

- H01: The share of innovative firms in ICT sectors is higher than the average of all sectors in the economy.

- H02: The share of business R\&D expenditure in the ICT sector is higher in Nordic countries compared to most of the new EU member states.

- H03: Higher business R\&D expenditure is positively related to higher apparent labour productivity in the ICT sector.

- H04: Higher business R\&D expenditure is positively related to higher business value-added in the ICT sector.

In order to test all four hypotheses and fulfil our main aim, we analyse available secondary empirical data. In this section, we describe our methodology as well as data in detail. Our dataset consists of macro-level business sector panel data from the Eurostat database. Hence, every indicator was captured yearly at a country level during the period 2008 - 2016 . All variables used in the regression analysis are described in more detail in Table 2.

The list of countries in the dataset originally consisted of EU28 countries plus Norway. However, Malta, Cyprus and Luxembourg were excluded from regression analysis due to unavailability of several indicators. 
Table 2

Description of variables used in the analysis.

\begin{tabular}{|c|c|c|}
\hline Variable & Description & Source (codes) \\
\hline BERD on GDP & $\begin{array}{l}\text { Business expenditure on R\&D (BERD) \% of gross } \\
\text { domestic product (GDP) }\end{array}$ & $\begin{array}{l}\text { Eurostat } \\
\text { (rd_e_berdindr2) }\end{array}$ \\
\hline BERD in $€$ & $\begin{array}{l}\text { Business expenditure on R\&D (BERD) in Euro per } \\
\text { inhabitant }\end{array}$ & $\begin{array}{l}\text { Eurostat } \\
\text { (rd_e_berdindr2) }\end{array}$ \\
\hline $\begin{array}{l}\text { Apparent } \\
\text { labour } \\
\text { productivity }\end{array}$ & $\begin{array}{l}\text { Apparent labour productivity (Gross value } \\
\text { added per person employed) - thousand euro }\end{array}$ & $\begin{array}{l}\text { Eurostat } \\
\text { Code: tin00152 }\end{array}$ \\
\hline Value Added & $\begin{array}{l}\text { Value-added at factor cost in production value } \\
\text { (in \%) }\end{array}$ & $\begin{array}{l}\text { Eurostat } \\
\text { Code: sbs_na_ind_r2 }\end{array}$ \\
\hline Personnel costs & $\begin{array}{l}\text { Average personnel costs (personnel costs per } \\
\text { employee) - thousand euro }\end{array}$ & $\begin{array}{l}\text { Eurostat } \\
\text { Code: } \\
\text { sbs_na_la_se_r2 }\end{array}$ \\
\hline GDP per capita & $\begin{array}{l}\text { GDP per capita in PPP: Volume indices of real } \\
\text { expenditure per capita in PPS (EU28 }=100 \text { ) }\end{array}$ & $\begin{array}{l}\text { Eurostat } \\
\text { Code: TEC00114 }\end{array}$ \\
\hline
\end{tabular}

Source: Authors' work

We analysed selected indicator related to business innovation and business investment to R\&D. In line with our first two hypotheses, we are especially focused on the share of innovative firms and share of business R\&D expenditure. We compared these indicators among selected European countries and come to several interesting findings. Furthermore, we constructed panel regression models to examine the potential link between business R\&D expenditure and selected financial business performance indicators. With respect to our main aim, results of previous studies and data availability we decided to focus on two main indicators: apparent labour productivity and value added at factor cost. We believe that especially these two indicators could be affected directly or indirectly by business investment into R\&D and potential innovation. Innovation could lead to both higher labour productivity as well as to higher value-added in production. However, it is likely that due to often longlasting innovation processes these potential effects on performance indicators can be delayed by several years. Hence, we also take into account time-lagged independent variables. In each case, we use either fixed effect or random effect panel regression models. Fixed effects models appear to be the more suitable ones. Despite this fact, we also have shown the results of the random-effects model due to robustness check. Moreover, we used independent variables capturing R\&D expenditure in two different forms (as \% of GDP and in Euro per capita) to further check the robustness. The results of the analysis are described in the next section.

\section{Results}

Based on our aim we examine business R\&D expenditures and innovation in the ICT sector. To get more detail view we separately compare the manufacturing and services sectors. In the first part of the analysis, we examine the share of innovative firms in ICT manufacturing and manufacturing sector in general. This has been done based on the sample of European OECD countries. As can be seen in Figure 1, the share of innovative firms (calculated as a share of firms that introduced product/process or marketing/organizational innovation) is higher in ICT manufacturing in all countries except Slovakia. In Slovakia, the share is almost similar in both types of manufacturing sectors. 
Figure 1

The total share of innovative firms in manufacturing in selected European countries

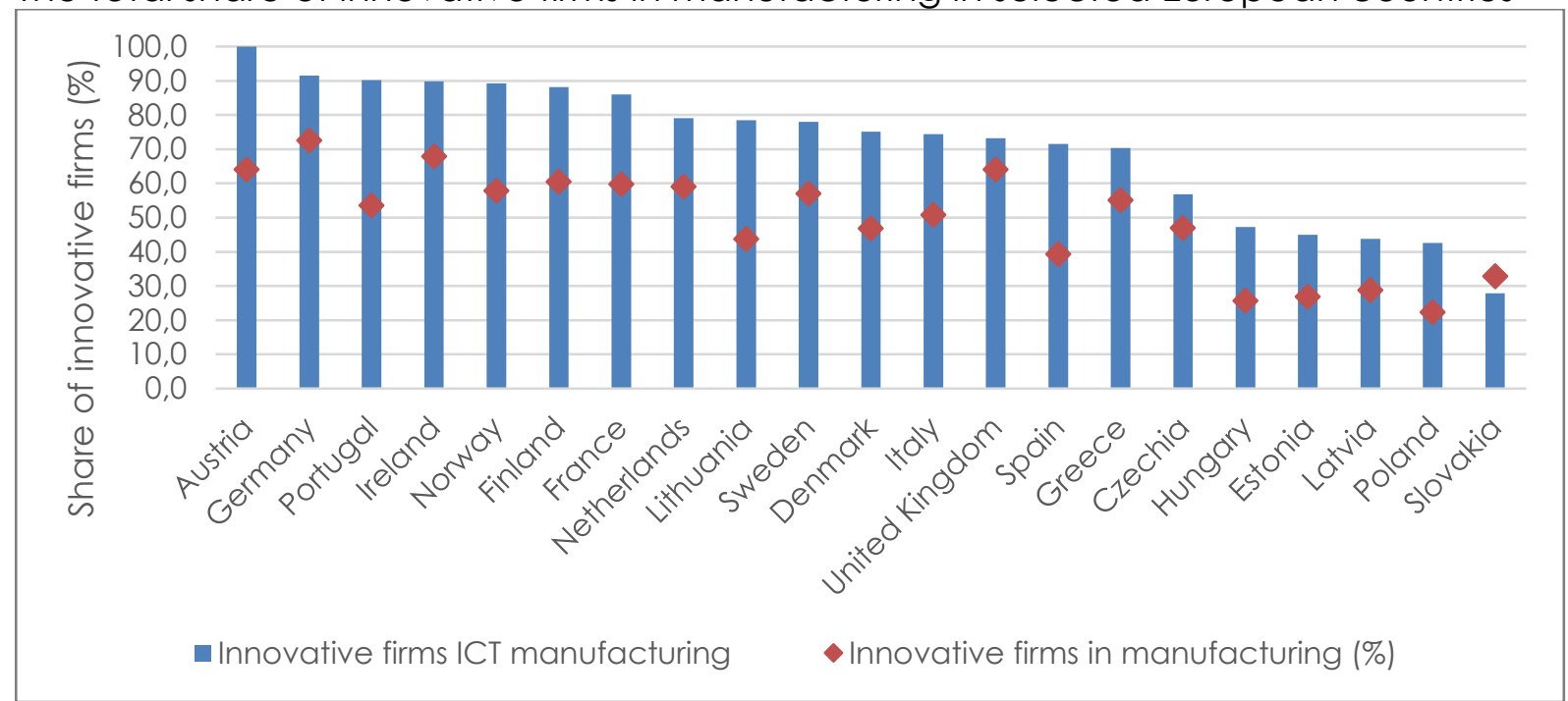

Source: Authors, based on "Innovation Indicators 2017" OECD database

Similarly, we also compare the share of innovative firms in IT services with the share of innovative firms in the services in general. As can be seen in Figure 2, firms with activities in IT services are on average more innovative in all selected countries. The difference is especially evident in countries such as Lithuania, Czechia, Latvia or Spain.

Figure 2

Share of innovative firms in services and IT services in European countries

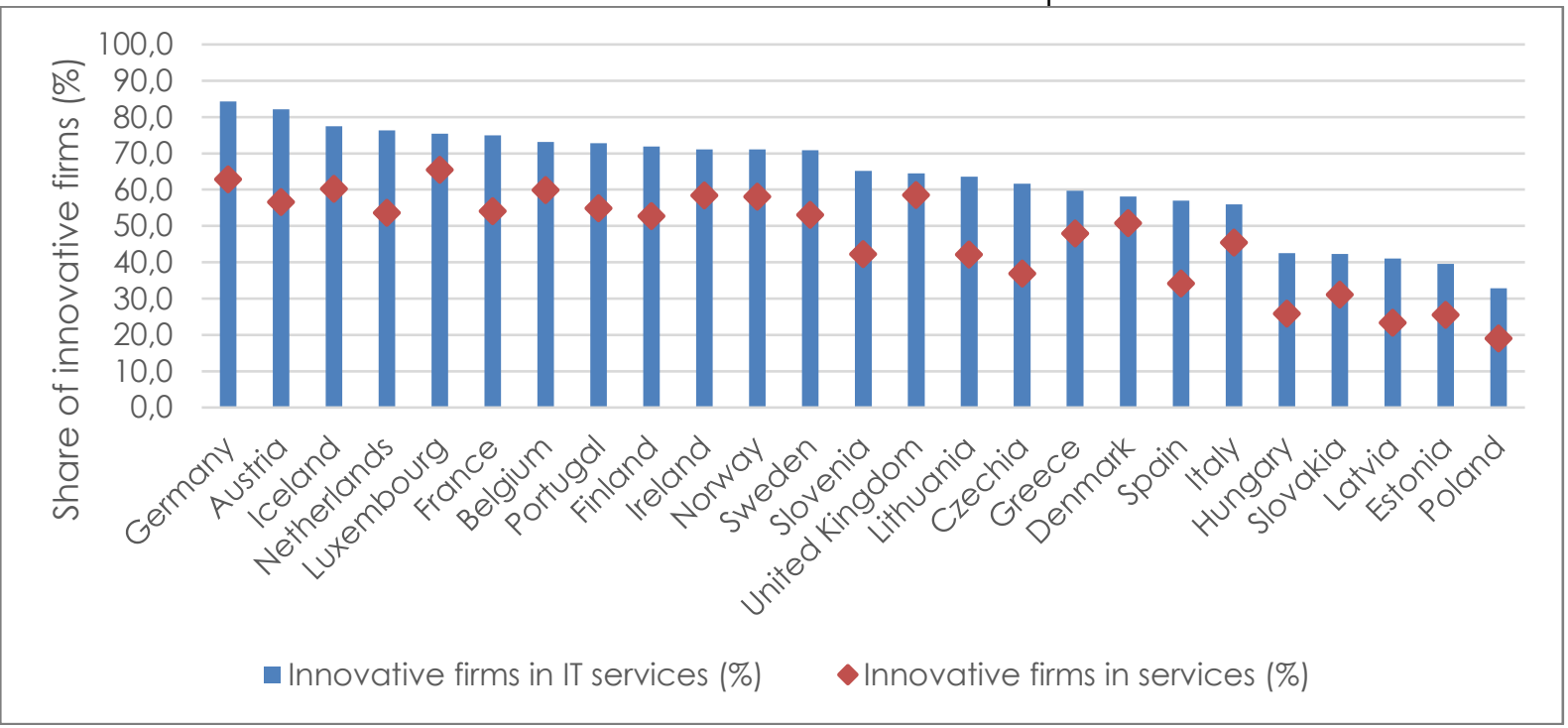

Source: Authors, based on "Innovation Indicators 2017" OECD database

In general, we can say that the ICT sector is more innovative than the average of the total economy. The differences between ICT firms and total economy are also particularly significant in countries such as Hungary, Poland, Latvia and Estonia, where the innovation performance, in general, is rather low.

In Figure 3 we compare business R\&D expenditure in ICT. This indicator was captured in euro per inhabitant as well as in percentage of GDP. Business R\&D expenditures are especially high in Nordic countries such as Island, Norway and Finland. Relatively high level of business R\&D expenditures to GDP is captured in 
Estonia, Bulgaria and Czechia. On the other hand, business R\&D expenditures in Latvia, Lithuania, Croatia, Greece and Slovakia are rather low in both indicators.

Figure 3

Business R\&D (BERD) expenditures in selected European countries in 2016

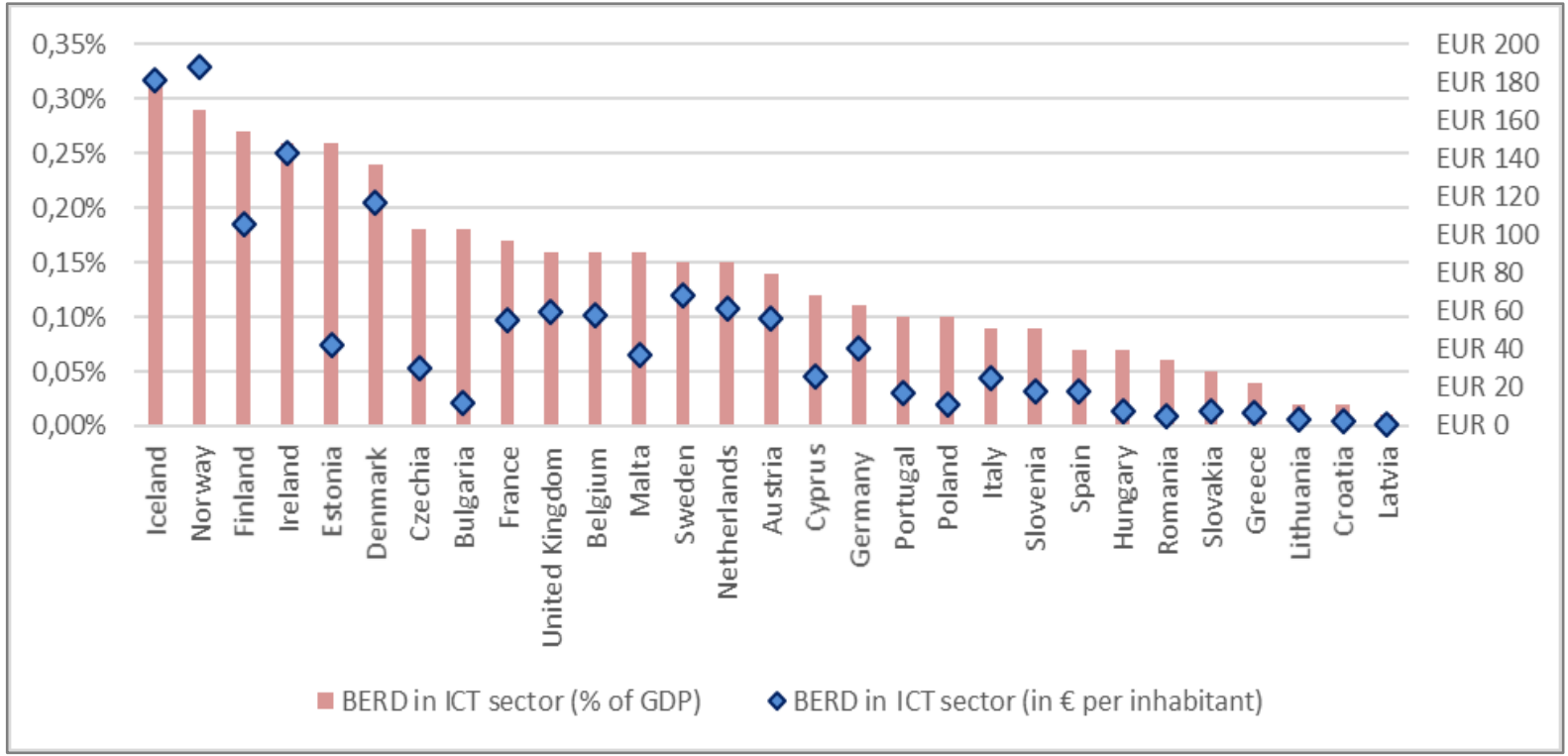

Source: Authors, based on Eurostat database (code: rd_e_berdindr2).

We also compared the share of business R\&D expenditure in the ICT sector to total business R\&D expenditure in each country. This is especially interesting when also comparing with the share of ICT sector production on total GDP. Both of these indicators can be seen in Figure 3. However, the data capturing the share of ICT on GDP was not available in Cyprus, Iceland, Ireland and Luxembourg. Despite a rather low proportion of ICT sector on the total economy in some countries, the share of R\&D expenditures in this sector is very high. This is particularly true in Cyprus where approximately $60 \%$ of total R\&D business expenditure is spent by firms in the ICT sector. Share of ICT sector on total R\&D expenditures is also very high in Malta, Estonia, Bulgaria and Ireland. This situation can be on one hand the result of lower R\&D investments in other sectors, which seems to be the case of Cyprus, Malta and on the other hand, this could be the reflection of very high R\&D expenditure in ICT sector despite the rather high business R\&D investment in the economy.

The ICT sector represents the highest share of the national economy in Malta followed by Sweden and the United Kingdom. In all three countries, the share of the ICT sector on GDP is higher than $6 \%$. 
Figure 4

Share of ICT sector on BERD and GDP in 2016

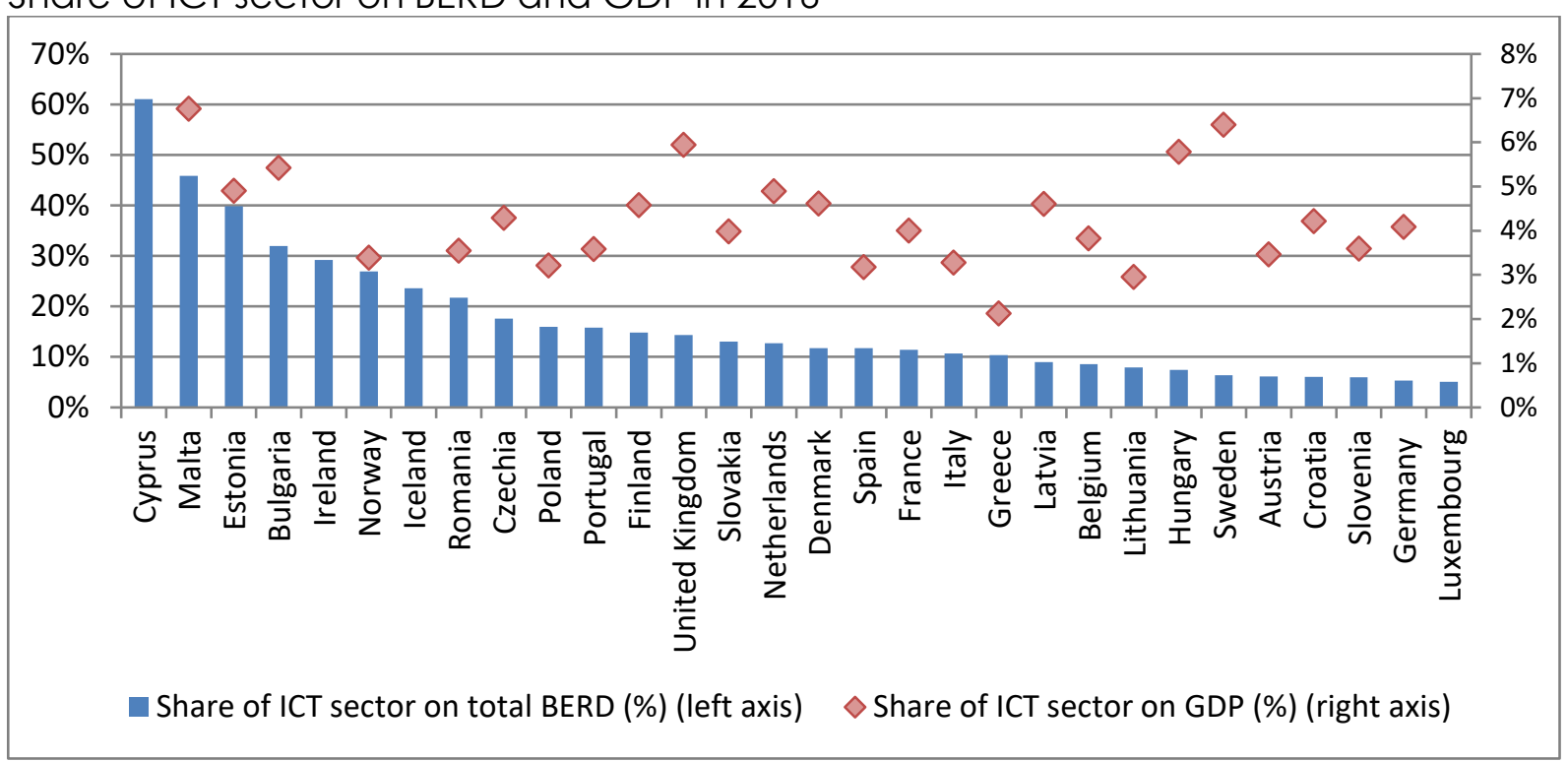

Source: Authors, based on Eurostat database (codes: rd_e_berdindr2; soc_bde15ag).

We conducted regression analysis. Based on the results we can examine potential relationships between $R \& D$ expenditure and selected business performance indicators. Firstly, we test the weak stationarity of our variables by several panel unitroot tests. The results are shown in Table 3. According to the majority of tests, we can conclude that all variables except personnel costs seem to be stationary at their levels in the selected period. In the case of personnel cost, we used first differences instead of level values to maintain weak stationarity of these variables.

Table 3

Results of panel unit root tests

\begin{tabular}{ccccc}
\hline & LLC tes $\dagger$ & IPS tes & ADF tes $\dagger$ & PP tes \\
\hline $\begin{array}{c}\text { Apparent Labour } \\
\text { productivity }\end{array}$ & $-6.120^{* * *}$ & $-2.36^{* * *}$ & $70.33^{* *}$ & $77.43^{* * *}$ \\
Value added & $-12.25^{* * *}$ & $-2.58^{* * *}$ & $72.83^{* * *}$ & $82.29^{* * *}$ \\
BERD(GDP) & $-9.07^{* * *}$ & -0.639 & $82.42^{* * *}$ & $67.70^{*}$ \\
\hline BERD( $€$ ) & $-7.327^{* * *}$ & -0.04 & $69.92^{* *}$ & $120.30^{* * * *}$ \\
Personnel costs & $-1.903^{* *}$ & 2.175 & 42.62 & 35.40 \\
$\Delta$ Personnel costs & $-10.58^{* * *}$ & $-4.01^{* * *}$ & $88.30^{* * *}$ & $86.68^{* * *}$ \\
Log(GDP per & $-19.454^{* * *}$ & $-6.14^{* * *}$ & $135.1^{* * *}$ & $98.28^{* * *}$ \\
capita) & & & & \\
\hline
\end{tabular}

Note: $/^{* *} / * * *$ denotes statistically significant at the 10/5/1 percent level.

Source: Authors based on the data from the Eurostat database.

Fin the first set of models we focus our attention on apparent labour productivity in the ICT sector. This indicator represents the dependent variable in the first set of regression models. The results of these panel regressions are summarised in Table 4 . We constructed seven fixed-effects regressions and one random effects regression. To capture potential delays in the actual impact of R\&D expenditures on labour productivity we also use lagged values of the main independent variable. The maximum number of lags were four due to a limited number of observations. This 
means that we captured the potential effect of R\&D expenditure on labour productivity delayed by one to four years. In addition to the share of business R\&D expenditures in the ICT sector on GDP, we also used the value of R\&D expenditures in euro per capita in some regressions. However, the results were very similar in both cases. This confirms the robustness of our results. We also used GDP per capita and personnel costs as two control variables. GDP per capita captures the potential effect of the economic cycle as well as differences in economic performance between countries. Personnel costs are used as a control variable for the potential effect of changes in salaries on productivity. These changes in personnel costs may also be the result of innovation and pressure on the use of highly skilled labour.

Table 4

Results of panel regression models

\begin{tabular}{|c|c|c|c|c|c|c|c|c|}
\hline \multicolumn{9}{|c|}{ Dependent variable: Apparent Labour productivity(in \%) } \\
\hline Lags/ years & 1.1 & 1.2 & 1.3 & 1.4 & 1.5 & 1.6 & 1.7 & 1.8 \\
\hline $\begin{array}{c}\text { BERD(GDP) } \\
\text { Lag }=0\end{array}$ & $\begin{array}{c}24.13^{* * *} \\
(2.43)\end{array}$ & & & & & & & \\
\hline $\begin{array}{l}\text { BERD(GDP) } \\
\text { Lag=1 year }\end{array}$ & & $\begin{array}{c}18.26^{* *} \\
(3.14)\end{array}$ & $\begin{array}{c}21.86^{* *} \\
(2.21)\end{array}$ & & & & & \\
\hline $\begin{array}{l}\text { BERD(GDP) } \\
\text { Lag=2 years }\end{array}$ & & & & $\begin{array}{c}6.54 \\
(0.83)\end{array}$ & & & & \\
\hline $\begin{array}{l}\text { BERD(GDP) } \\
\text { Lag=3 years }\end{array}$ & & & & & $\begin{array}{l}26,47^{*} \\
(1.70)\end{array}$ & & & \\
\hline $\begin{array}{l}\text { BERD(GDP) } \\
\text { Lag=4 years }\end{array}$ & & & & & & $\begin{array}{c}16.53^{* *} \\
(2.06)\end{array}$ & & \\
\hline $\begin{array}{c}\text { BERD }(€) \\
\text { Lag=1 year }\end{array}$ & & & & & & & $\begin{array}{c}0.18^{* * *} \\
(8.12)\end{array}$ & \\
\hline $\begin{array}{c}\text { BERD(€) } \\
\text { Lag=2 years }\end{array}$ & & & & & & & & $\begin{array}{c}0.11^{* * *} \\
(3.27)\end{array}$ \\
\hline $\begin{array}{l}\Delta \text { Personnel } \\
\text { costs }\end{array}$ & $\begin{array}{c}0.77^{* * *} \\
(3.66)\end{array}$ & $\begin{array}{c}0.76^{* * *} \\
(3.67)\end{array}$ & $\begin{array}{l}0.70^{* *} \\
(2.29)\end{array}$ & $\begin{array}{c}0.54^{* * *} \\
(3.14)\end{array}$ & $\begin{array}{c}0.56^{* * *} \\
(2.98)\end{array}$ & $\begin{array}{l}0.60 * * \\
(2.32)\end{array}$ & $\begin{array}{c}0.96^{* * *} \\
(5.38)\end{array}$ & $\begin{array}{c}0.68^{* * *} \\
(3.77)\end{array}$ \\
\hline $\begin{array}{l}\log (\text { GDP per } \\
\text { capita) }\end{array}$ & $\begin{array}{c}-5.2 \\
(-1.77)\end{array}$ & $\begin{array}{c}-5.1 \\
(-1.24)\end{array}$ & $\begin{array}{c}35.4^{* * *} \\
(3.93)\end{array}$ & $\begin{array}{c}-6.4 \\
(-0.64)\end{array}$ & $\begin{array}{l}-28.7^{*} \\
(-1.69)\end{array}$ & $\begin{array}{l}-57.7^{* * *} \\
(-14.29)\end{array}$ & $\begin{array}{c}-7.2 \\
(-1.48)\end{array}$ & $\begin{array}{c}-9.9 \\
(-1.02)\end{array}$ \\
\hline C & $\begin{array}{c}84.05^{* * *} \\
(4.23)\end{array}$ & $\begin{array}{c}84.4^{* * *} \\
(4.56)\end{array}$ & $\begin{array}{c}-93.18^{* *} \\
(-2.48)\end{array}$ & $\begin{array}{c}91.68^{* * *} \\
(2.09)\end{array}$ & $\begin{array}{l}187.8 \\
(2.55)\end{array}$ & $\begin{array}{c}316.8^{* * *} \\
(17.99)\end{array}$ & $\begin{array}{c}89.9^{* * *} \\
(4.06)\end{array}$ & $\begin{array}{c}104.2^{* *} \\
(2.44)\end{array}$ \\
\hline $\begin{array}{l}\text { Cross-section } \\
\text { Fixed effect } \\
\text { (FE)/ Random } \\
\text { effects (RE) }\end{array}$ & FE & FE & RE & FE & $\mathrm{FE}$ & $\mathrm{FE}$ & FE & FE \\
\hline $\mathbf{R} 2$ & 0.98 & 0.98 & 0.21 & 0.98 & 0.99 & 0.99 & 0.98 & 0.99 \\
\hline Adjusted R2 & 0.98 & 0.98 & 0.19 & 0.98 & 0.98 & 0.98 & 0.98 & 0.98 \\
\hline F-statistic & $343.3^{* * *}$ & 337.3* & $13.2^{* * *}$ & $352.5^{* * *}$ & $463.9 * * *$ & $403.2^{* * *}$ & $367.8^{* * *}$ & $363.3^{* * *}$ \\
\hline
\end{tabular}

Note: symbols (.) denotes t-statistics and */**/** denotes statistically significant at the $10 / 5 / 1$ percent level. Standard errors have been corrected for heteroscedasticity. The maximum number of observations in panel data is 168 .

Source: Authors based on the data from the Eurostat database.

As can be seen in Table 4, business R\&D expenditure in ICT sector seems to be positively correlated with apparent labour productivity in the ICT sector. This is true in all models, even though in the model with a two-year time lag, this relationship appears to be statistically not significant. The positive correlation on labour productivity is evident even in the same year R\&D expenditure has been invested. This relationship is significant at $5 \%$ level of significance in this instance as well as with oneyear time lag. We also find evidence that this effect can persist for several next years, which is captured by a positive and statistically significant coefficient in the third and fourth year. In the case of R\&D expenditure in euro per capita, this is evident in the 
case of both one- and two-year lags and it is statistically significant even at $1 \%$ level of significance.

Similarly, we also found a positive correlation between an increase in personnel costs and labour productivity. The variable GDP per capita was mostly statistically insignificant.

In the second set of regression models, we use value-added as the dependent variable. This time we used a log of value-added because value-added is the variable expressed in euro and we need to reduce the extreme values and into some extent normalise the distribution of this variable. The results of regressions are summarised in Table 5. We assume that higher business R\&D expenditure in ICT sector should be positively correlated with the higher benefit in the sector. This again may be more evident with a certain time lag. Hence, we again applied also lagged independent variables. We used eight regressions with fixed effects and one regression with random effects to check the robustness. In one case, we also used the common logarithm of the independent variable to capture potential non-linear relationships in log-log form and further test the robustness of our results.

Table 5

Results of panel regression models

\begin{tabular}{|c|c|c|c|c|c|c|c|c|c|}
\hline \multicolumn{10}{|c|}{ Dependent variable: Log(Value added) (in mil. $€$ ) } \\
\hline Lags/ years & 1.1 & 1.2 & 1.3 & 1.4 & 1.5 & 1.6 & 1.7 & 1.8 & 1.9 \\
\hline $\begin{array}{l}\mathrm{BERD}(\mathrm{GDP}) \\
\mathrm{Lag}=0\end{array}$ & $\begin{array}{r}0.374 \\
(1.38)\end{array}$ & & & & & & & & \\
\hline $\mathrm{BERD}(\mathrm{GDP})$ & & $0.92 * * *$ & $0.64^{*}$ & & & & & & \\
\hline Lag $=1$ year & & (3.34) & $(1.67)$ & & & & & & \\
\hline $\begin{array}{l}\log (B E R D(G D P)) \\
\operatorname{Lag}=1 \text { year }\end{array}$ & & & & $\begin{array}{r}0.05^{* * *} \\
(3.98)\end{array}$ & & & & & \\
\hline BERD (GDP) & & & & & $0.76^{* *}$ & & & & \\
\hline $\mathrm{BERD}(\mathrm{GDP})$ & & & & & & $0.71 *$ & & & \\
\hline $\operatorname{Lag}=3$ years & & & & & & (1.95) & & & \\
\hline BERD(GDP) & & & & & & & $1.01^{* * *}$ & & \\
\hline Lag $=4$ years & & & & & & & (3.12) & & \\
\hline $\begin{array}{l}\operatorname{BERD}(€) \\
\operatorname{Lag}=1 \text { year }\end{array}$ & & & & & & & & $\begin{array}{r}0.002^{* * *} \\
(2.68)\end{array}$ & \\
\hline $\begin{array}{l}\text { BERD }(€) \\
\operatorname{Lag}=2 \text { years }\end{array}$ & & & & & & & & & $\begin{array}{r}0.002^{* * *} \\
(3.68)\end{array}$ \\
\hline $\begin{array}{l}\triangle \text { Personnel } \\
\text { costs }\end{array}$ & $\begin{array}{r}-0.0002 \\
(-0.14)\end{array}$ & $\begin{array}{r}0.0002 \\
(0.19)\end{array}$ & $\begin{array}{l}-0.002 \\
(-0.10)\end{array}$ & $\begin{array}{l}0.0009 \\
(0.006)\end{array}$ & $\begin{array}{r}-0.0001 \\
(-0.07)\end{array}$ & $\begin{array}{r}0.002^{*} \\
(1.88)\end{array}$ & $\begin{array}{r}0.0002 \\
(1.51)\end{array}$ & $\begin{array}{r}0.09 \\
(0.44)\end{array}$ & $\begin{array}{l}0.002 \\
(0.94)\end{array}$ \\
\hline $\begin{array}{l}\text { Log(GDP per } \\
\text { capita) }\end{array}$ & $\begin{array}{r}0.11 \\
(0.46)\end{array}$ & $\begin{array}{r}-0.03 \\
(-0.11)\end{array}$ & $\begin{array}{r}0.05 \\
(0.31)\end{array}$ & $\begin{array}{r}-0.05 \\
(-0.15)\end{array}$ & $\begin{array}{r}0.33^{* * *} \\
(4.11)\end{array}$ & $\begin{array}{l}0.25^{* *} \\
(2.02)\end{array}$ & $\begin{array}{r}-0.14 \\
(-1.25)\end{array}$ & $\begin{array}{r}0.09 \\
(0.44)\end{array}$ & $\begin{array}{r}0.37^{* * *} \\
(4.02)\end{array}$ \\
\hline C & $\begin{array}{r}3.24^{* * *} \\
(3.07)\end{array}$ & $\begin{array}{r}3.81^{* * *} \\
(3.01)\end{array}$ & $\begin{array}{r}- \\
93.2^{* *} \\
(-2.48)\end{array}$ & $\begin{array}{l}4.09^{* *} \\
(3.07)\end{array}$ & $\begin{array}{r}2.20^{* * *} \\
(6.19)\end{array}$ & $\begin{array}{r}2.60^{* * *} \\
(4.58)\end{array}$ & $\begin{array}{r}4.03^{* * *} \\
(8.98)\end{array}$ & $\begin{array}{r}3.27^{* * *} \\
(3.46)\end{array}$ & $\begin{array}{r}2.09^{* * * *} \\
(5.32)\end{array}$ \\
\hline $\begin{array}{l}\text { Cross-section Fixed } \\
\text { effect (FE)/ } \\
\text { Random effects } \\
\text { (RE) }\end{array}$ & $\mathrm{FE}$ & FE & $\mathrm{RE}$ & FE & FE & $\mathrm{FE}$ & $\mathrm{FE}$ & FE & $\mathrm{FE}$ \\
\hline R2 & 0.88 & 0.89 & 0.04 & 0.90 & 0.92 & 0.92 & 0.9 & 0.89 & 0.91 \\
\hline Adjusted R2 & 0.87 & 0.87 & 0.02 & 0.88 & 0.90 & 0.90 & 0.88 & 0.87 & 0.89 \\
\hline F-statistic & $43.1^{* * *}$ & $46.69^{*}$ & $12.22^{*}$ & $45.69^{* * *}$ & $47.93^{* * *}$ & $42.37^{* * *}$ & $42,6^{* * *}$ & $43.19^{* * *}$ & $47.38^{* * *}$ \\
\hline
\end{tabular}

Note: symbols (.) denotes t-statistics and */***** denotes statistically significant at the $10 / 5 / 1$ percent level. Standard errors have been corrected for heteroscedasticity. The maximum number of observations in panel data is 168 .

Source: Authors based on the data from the Eurostat database.

As can be seen from the results, we again found evidence for the positive correlation between R\&D expenditure and value added at factor cost in production. As we assumed the relationship is not evident in the same period, but R\&D expenditure from previous years appears to be positive and statistically significant. This is true in the 
case of all four lagged independent variables. Similarly, a positive and significant correlation with value-added is evident for both indicators expressed as a percentage of GDP as well as in euro per capita.

Our findings help us fulfil our main scientific aim and based on them we can test four main scientific hypotheses as mentioned in the methodological section of our paper. Concerning our research hypotheses, we can make these conclusions.

Firstly, we cannot reject the hypothesis $\mathrm{HOl}$ that the share of innovative firms in ICT sectors is higher than the average of all sectors in the economy. In fact, our results strongly suggest that this is true in all selected European countries.

Secondly, the hypothesis H02 that the share of business R\&D expenditure in the ICT sector is higher in Nordic countries compared to most of new EU member states is not rejected. Most of the Nordic countries such as Norway, Island and Finland reach the highest business expenditures on R\&D in our sample.

We fail to reject the third hypothesis that the higher business R\&D expenditures are positively related to higher appetent labour productivity in the ICT sector. Our data support the existence of relationship between these two variables in the same period as well as with a certain time delay.

Finally, we also found no evidence that the hypothesis $\mathrm{HO} 4$ should be rejected. Our results suggest that higher business R\&D expenditure is positively related to higher business value-added in the ICT sector. The business R\&D expenditure is positively correlated with value added at factor cost in ICT. This time we found a positive correlation of business R\&D from previous periods and value-added in the current period.

Higher business investment in R\&D seems to be at least positively correlated with selected business performance indicators namely labour productivity and valueadded in the ICT sector. These results are in line with the results of several other previous studies. While the positive effect of R\&D expenditures on productivity has been previously found for example by Pieri et al. (2018), Khanna and Sharma (2018) and Martin and Nguyen-Thi (2015), the positive impact on value-added has been reported for example by Edquist and Henrekson (2017). Potential effect on labour productivity can likely be achieved mostly by the innovation of processes in the ICT sector. On the contrary, an increase in value-added can be to a certain extent explained by the innovation of ICT product or services.

It is also important to mention several limitations of our approach. It should be taken caution when interpreting the results of our regression model strictly as causalities. Despite our best effort in reducing the endogeneity problem by including control variables and using lagged values of independent variables, this problem could not be completely ruled out. Hence, it is still more accurate to perceive our results as correlation or as potential causal effects. Next limitation lies in our dataset. We have been limited by data availability as well as the structure of the data. Due to this fact, we decided to use macro-level data for the sector rather than micro-level data for individual firms. Additional analysis of similar indicators on the firms' level could significantly complement our results and provide some additional findings for the causes and consequences of examined issues.

\section{Conclusion}

Based on our results we can conclude that the ICT sector represents an important element of innovation performance in the country, Firms in the ICT sector are more innovative than the average of firms in the total economy. This is true in all European countries in our sample. Furthermore, firms in the ICT sector account for a significant share of total business R\&D expenditure in the economy in most countries. The highest 
proportion of R\&D expenditures in ICT on GDP was captured in Nordic countries such as Island, Norway and Finland. However, several Eastern European countries such as Estonia and Bulgaria are also performing very well in this indicator despite lower business R\&D investment in Euro per capita. On the other hand, countries such as Latvia, Lithuania, Greece, Croatia and Slovakia still have only a very small proportion of business R\&D in the ICT sector.

In line with our findings, we can also conclude that business investment in R\&D is positively correlated with certain business performance indicators. In our case, we found evidence of a positive relationship between R\&D expenditure and apparent labour productivity as well as value-added in the ICT sector. Both indicators seem to be potentially affected by R\&D expenditures in previous years. However, the relationship with productivity was evident also in the same period. We assume that the mentioned results can be to some extent attributed to the development of process and product innovations. This can have several consequences for the business sector as well as for innovation policies. Business investment in R\&D expenditure can improve the economic performance of firms in the future. This can be also reflected in the governmental innovation policy. Increase in business R\&D expenditure can be achieved by indirect innovation support. For this purpose, special tax treatment can be applied such as immediate write-off of current R\&D expenditures or R\&D tax credit. Our research shed some light on the current state and potential consequences of business R\&D investment. However, even more, empirical research especially is needed in this area to examine this problem in more detail.

\section{References}

1. Abdal, A., Torres-Freire, C. E., Callil, V. (2016), "Rethinking sectoral typologies: A classification of activity according to knowledge and technological intensity", RAI Revista de Administração e Inovação, Vol. 13 No. 4, pp. 232-241.

2. Agramunt, L. F., Berbel-Pineda, J. M. (2018), "The positive moderating effect of absorptive capacity on R\&D investment: The case of Argentina's ICT firms", Annals of the Brazilian Academy of Sciences, Vol. 90 No. 3, pp. 3207-3221.

3. Akcali, B. Y., Sismanoglu, E. (2015), "Innovation and the effect of research and development (R\&D) expenditure on growth in some developing and developed countries", Procedia - Social and Behavioral Sciences, Vol. 195, pp. 768-775.

4. Álvarez, R. (2016), "The impact of R\&D and ICT investment on innovation and productivity in Chilean firms", Working paper wp428, University of Chile, Department of Economics, September 2016.

5. Apergis, N., Sorros, J. (2014), "The role of R\&D expenses for profitability: Evidence from U.S. Fossil and renewable energy firms", International Journal of Economics and Finance, Vol. 6 No. 3, pp. 8-15.

6. Ayaydin, H., Karaaslan, I. (2014), "The effect of research and development investment on firms' financial performance: Evidence from manufacturing firms in Turkey", The Journal of Knowledge Economy \& Knowledge Management, Vol. IX, pp. 23-39.

7. Babkin, A. V., Lipatnikov, V. S., Muraveva, S. V. (2015), "Assessing the impact of innovation strategies and R\&D costs on the performance of IT companies", Procedia Social and Behavioral Sciences, Vol. 207, pp. 749-758.

8. Blanco, L., GU, J., Prieger, J. E. (2015), "The impact of research and development on economic growth and productivity in the U. S. States", Southern Economic Journal, Vol. 82 No. 3, pp. 914-934.

9. Canarella, G., Miller, S. M. (2018), "The determinants of growth in the U.S. information and communication technology (ICT) industry: A firm-level analysis", Economic Modelling, Vol. 70, pp. 259-271.

10. Czarnitzki, D., Thorwarth, S. (2012), "Productivity effects of basic research in low-tech and high-tech industries", Research Policy, Vol. 41 No. 9, pp. 1555-1564. 
11. Edquist, H., Henrekson, M. (2017), "Swedish lessons: How important are ICT and R\&D to economic growth?", Structural Change and Economic Dynamics, Vol. 42, pp. 1-12.

12. Estrada, I., Dong, J. Q. (2020), "Learning from experience? Technological investments and the impact of coopetition experience on firm profitability", Long Range Planning, Vol. 53 No 1. Article 101866.

13. Falk, M. (2007), "R\&D spending in the high-tech sector and economic growth", Research in Economics, Vol. 61, pp. 140-147.

14. Freihat, A. R., Kanakriyah, R. (2017), "Impact of R\&D expenditure on financial performance: Jordanian evidence", European Journal of Business and Management, Vol. 9 No. 32, pp. 73-83.

15. Gumus, E., Celikay, F. (2015), "R\&D expenditure and economic growth: New empirical evidence", Margin - The Journal of Applied Economic Research, Vol. 9 No. 3, pp. 205217.

16. Hall, B. H., Lotti, F., Mairesse, J. (2013), "Evidence on the impact of R\&D and ICT investments on innovation and productivity in Italian firms", Economics of Innovation and New Technology, Vol. 22 No. 3, pp. 300-328.

17. Hanna, N. K. (2009), Enabling Enterprise Transformation, Springer, New York.

18. Hong, J. (2016), "Causal relationship between ICT R\&D investment and economic growth in Korea", Technological Forecasting and Social Change, Vol. 116, pp. 70-75.

19. Huňady, J., Orviská, M. (2014), "The impact of research and development expenditures on innovation performance and economic growth of the country - the empirical evidence", in Hájek, P., Mumanachit, P. (Eds.), CBU International Conference Innovation, Technology Transfer and Education (Vol. 2), 3-5 February, Central Bohemia University, o.p.s., Prague, pp. 119-125.

20. Karahan, Ö. (2015), "Intensity of business enterprise R\&D expenditure and high-tech specification in European manufacturing sector", Procedia - Social and Behavioral Sciences, Vol. 195, pp. 806-813.

21. Khanna, R., Sharma, Ch. (2018), "Testing the effect of investments in IT and R\&D on labour productivity: New method and evidence for Indian firms", Economic Letters, Vol. 173, pp. 30-34.

22. Koutroumpis, P., Leiponen, A., Thomas, L. D. W. (2020), "Small is big in ICT: The impact of R\&D on productivity", Telecommunications Policy, Vol. 44 No. 1, Aricle 101833.

23. Lee, H. S., Mun, H. W., Lee, S.-Y. (2018), "Profitability determinants of information technology software companies in Malaysia", Advanced Science Letters, Vol. 24 No. 2, pp. 1514-1518.

24. Lindmark, S., Turlea, G., Ulbrich, M. (2010), "Business R\&D in the ICT sector: Examining the European ICT R\&D deficit", Science and Public Policy, Vol. 37 No. 6, pp. 413-428.

25. Manjón, J. V. G., Mompó, R., Redoli, J. (2016), "Accelerating Innovation in small and medium-sized enterprises in the ICT services sector", SAGE Open, Vol. 6 No. 3, pp. 1-9.

26. Martin, L., Nguyen-Thi, T. U. (2015), "The relationship between innovation and productivity based on R\&D and ICT use", Revue Économique, Vol. 66 No. 6, pp. 11051130.

27. Mithas, S., Tafti, A., Bardhan, I., Goh, J. M. (2012), "Information technology and firm profitability: Mechanisms and empirical evidence", MIS Quarterly, Vol. 36 No. 1, pp. 205224.

28. Mohnen, P., Polder, M., van Leeuwen, G. (2018), "ICT, R\&D and organizational innovation: Exploring complementarities in investment and production", Working Paper 25044, National Bureau of Economic Research, Cambridge, 2018.

29. Monge-González, R., Hewitt, J. (2010), "Innovation, R\&D and productivity in the Costa Rican ICT sector: A case study", IDB Working paper series No. IDB-WP-189, InterAmerican Development Bank, June 2010.

30. Nekrep, A., Strašek, S., Boršič, D. (2018), "Productivity and economic growth in the European Union: Impact of investment in research and development", Naše gospodarstvo/Our Economy, Vol. 64 No. 1, pp. 18-27. 
31. Park, E., Kim, K. J., Kwon, S. J., Ohm, J. Y., Del Pobil, A. P., \& Yoo, K. (2016). "Determinants for the success of regional ICT ventures: a close examination of South Korea.", SpringerPlus, No. 5, 1039, (2016). 2016, pp.1-8.

32. Park, J. H., Lee, B., Moon, Y. H., Kim, G., Kwon, L. N. (2018), "Relation of R\&D expense to turnover and number of listed companies in all industrial fields", Journal of Open Innovation: Technology, Market and Complexity, Vol. 4 No. 1, pp. 1-15.

33. Pieri, F., Vecchi, M., Venturini, F. (2018), "Modelling the joint impact of R\&D and ICT on productivity: A frontier analysis approach", Research Policy, Vol. 47 No. 9, pp. 18421852.

34. Sandu, S., Ciocanel, B. (2014), "Impact of R\&D and innovation of High-tech Export", Procedia Economics and Finance, Vol. 15 pp. 80-90.

35. Schröder, Ch. (2012), "Differences between high growth and low growth ICT firms in Germany", In Welfens, P. J. J. (Ed.), Clusters in Automotive and Information \& Communication Technology: Innovation, Multinationalization and Networking Dynamics, Springer, Berlin, pp. 135-183.

36. Sepehrdoust, H. (2018), "Impact of information and communication technology and financial development on the economic growth of OPEC developing economies", Kasetsart Journal of Social Sciences, Advance online publication.

37. Shen, K.-Y., Yan, M.-R., Tzeng, G.-H. (2017), "Exploring R\&D influences on financial performance for business sustainability considering dual profitability objectives", Sustainability, Vol. 9 No. 11, pp. 1-21.

38. Stejskal, J., Hajek, P., Prokop, V. (2018), "Collaboration and innovation models in information and communication creative industries - the case of Germany", Journal of Information and Communication Technology, Vol. 17 No. 2, pp. 191-208.

39. Tolica, E. K., Sevrani, K., Gorica, K. (2015), Information Society Development Through ICT Market Strategies, Springer, Cham.

40. Tsang, E. W. K., Yip, P. S. L., Toh, M. H. (2008), "The impact of R\&D on value-added for domestic and foreign firms in a newly industrialized economy", International Business Review, Vol. 17, pp. 423-441.

41. Turlea, G., Nepelski, D., De Prato, G., Simon, J.P., Sabadash, A., Stancik, J., Szewczyk, W., Desruelle, P., Bogdanowicz, M. (2009), The 2009 Report on R\&D in ICT in the European Union, The Office for Official Publications of the European Communities, Luxembourg.

42. VanderPal, G. A. (2015), "Impact of R\&D expenses and corporate financial performance", Journal of Accounting and Finance, Vol. 15 No. 7, pp. 135-149.

43. Wang, D. H.-M., YU, T. H.-K., Liu, H.-Q. (2013), "Heterogeneous effect of high-tech industrial R\&D spending on economic growth", Journal of Business Research, Vol. 66 No. 10, pp. 1990-1993.

44. Warusawitharana, M. (2015), "Research and development, profits and firm value: A structural estimation", Quantitative Economics, Vol. 6, pp. 531-565.

45. Wei, Y. H. D., Liegner, I., Miao, Ch.-H. (2011), "Network configurations and R\&D activities of the ICT industry in Suzhou municipality, China", Geoforum, Vol. 42 No. 6, pp. 484-495. 


\section{About the authors}

Jan Hunady, PhD. is an assistant professor at the Faculty of Economics, Matej Bel University in Banska Bystrica, Slovakia. He received his PhD in public economics and services. He has published a number of papers in journals such as Transportation Research Part A: Policy and Practice, Information Polity and Engineering Economics. His research interests are focused on public finance, institutions, innovation and technology. He participates in several research projects in the area of research policy and innovation. His expertise is also in econometrics and econometrics programs, particularly panel data and time series analysis. The author can be contacted at jan.hunady@umb.sk.

Peter Pisar, PhD. is an associate professor of finance, banking and investment at Matej Bel University. He was the Head of Department of Finance and Accounting from 2015 to 2018. His research is focused on European public finances, especially innovation, innovative financing and the evaluation of regional policy and public expenditure programs. In practice, he is also a consultant for the development and implementation of projects supported by EU funds and is particularly concerned with public policies supporting innovation. The author can be contacted at peter.pisar@umb.sk.

Ina Durcekova is an internal doctoral student at the Faculty of Economics, Matej Bel University in Banska Bystrica, at the department of finance and accounting. Her research is focused on innovation and public funding of innovation. The author can be contacted at ina.durcekova@umb.sk. 